\title{
Keefektifan Model Snowball Throwing Berbantu Media Cakram Kariku Terhadap Hasil Belajar Siswa Pada Pembelajaran Tematik Subtema 2
}

\author{
Khusna Maulida Yusriyanti ${ }^{1}$, Arfilia Wijayanti ${ }^{2}$, Anggun Dwi Setya P3
}

${ }^{123}$ Jurusan Pendidikan Guru Sekolah Dasar, Fakultas Ilmu Pendidikan Universitas PGRI Semarang

\section{ARTICLEINFO}

Article history:

Received 18 May 2019

Received in revised form 30 June 2019

Accepted 15 July 2019

Available online 25 August 2019

\section{Kata Kunci:}

Model Snowball Throwing, media cakram kariku, hasil belajar

Keywords:

Snowball Throwing model, disc media kariku, learning outcomes

\begin{abstract}
A B S T R A K
Penelitian ini bertujuan untuk mengetahui keefektifan model Snowball Throwing berbantu media cakram cariku terhadap hasil belajar siswa pada pembelajaran tematik subtema 2 kelas IV SD Negeri 02 Kemijen Semarang. Subjek dalam penelitian ini yaitu seluruh siswa kelas IV SD Negeri 02 Kemijen Semarang tahun ajaran 2018/2019. Penelitian ini merupakan penelitian eksperimen dengan pendekatan kuantitatif. Desain penelitian ini yaitu penelitian pre-eksperimental dengan jenis penelitian one group pretest-posttest design dan teknik sampling yang digunakan yaitu non probability sampling. Teknik pengumpulan data menggunakan teknik pengumpulan data tes, observasi dan dokumentasi. Hasil penelitian menunjukkan bahwa perhitungan nilai hasil belajar pretest dan posttest terdapat berbedaan. Berdasarkan olah data menggunakan uji-t diperoleh $t_{\text {hitung }}$ sebesar 11,264 dan $t_{\text {tabel }}$ sebesar 2,064 atau $t_{\text {hitung }}>t_{\text {tabel }}$ yaitu 11,264>2,064, maka $\mathrm{H}_{0}$ ditolak dan $\mathrm{H}_{\mathrm{a}}$ diterima sehingga dapat disimpulkan bahwa model Snowball Throwing berbantu media cakram kariku efektif terhadap hasil belajar siswa pada pembelajaran tematik subtema 2 kelas IV SD Negeri 02 Kemijen Semarang.
\end{abstract}

\section{A B S T R A C T}

This study aims to determine the effectiveness of Snowball Throwing models with disk media in student learning outcomes in the thematic learning sub-theme 2 fourth grade of State Elementary School 02 Kemijen Semarang. The subjects in this study were all fourth grade students of Semarang State Elementary School 02 Kemijen 2018/2019. This research is an experimental study with a quantitative approach. The design of this study is pre-experimental research with one group pretest-posttest design research and the sampling technique used is non probability sampling. Data collection techniques are the collecting test data, observation and documentation. The results showed that the calculation of the learning outcomes of the pretest and posttest was different. Based on the data processing using the t-test obtained tcount of 11.264 and ttable of 2.064 or tcount> ttable that is 11.264> 2.064, then $\mathrm{HO}$ is rejected and $\mathrm{Ha}$ is accepted so it can be concluded that Snowball Throwing model is supported by disc media kariku effective on student learning outcomes in thematic learning sub-theme 2 of grade IV SDN 02 Kemijen Semarang.

\footnotetext{
${ }^{1}$ Corresponding author.

E-mail addresses: khusnamaulida21@Gmail.com (Khusna Maulida Yusriyanti)
} 


\section{Pendahuluan}

Pendidikan adalah hal terpenting bagi setiap negara untuk dapat berkembang pesat. Negara yang hebat akan menempatkan pendidikan sebagai prioritas pertamanya, karena dengan pendidikan, kemiskinan pada rakyat di negara tersebut akan dapat tergantikan menjadi kesejahteraan. Bagaimanapun, dalam perkembangannya, pendidikan di Indonesia senantiasa harus menghadapi beberapa masalah di setiap tahapnya. Masalahmasalah tersebut hanya dapat diselesaikan dengan partisipasi dari semua pihak yang terkait di dalam sistem pendidikan, seperti orangtua, guru-guru, kepala sekolah, masyarakat, dan juga peserta didik itu sendiri. Pada fase input, orangtua memiliki kontribusi besar dalam memperkenalkan nilai-nilai baik kepada anak-anak mereka. Orangtua bertanggung jawab penuh untuk mendidik anak-anak mereka dengan nilai-nilai kepemimpinan, sehingga mereka mempunyai bekal yang cukup untuk menjadi cikal bakal pemimpin ketika mereka mulai memasuki institusi formal, seperti sekolah. Pada fase proses, orangtua bekerjasama dengan para guru dan kepala sekolah untuk memberikan penguatan kepada peserta didik dalam menerapkan nilai-nilai kepempinan yang baik melalui budaya organisasi di sekolah. Terakhir, pada tahap output, peserta didik harus menghadapi begitu banyak tantangan di dunia nyata, di luar sekolah. Peserta didik yang sudah melalui tahap-tahap sebelumnya di sekolah dengan budaya organisasi yang mengajarkan dan membiasakan nilai-nilai baik dalam hidupnya, maka akan tumbuh menjadi pemimpin yang hebat untuk negara ini (Megawanti, 2012).

Pendidikan juga merupakan sebuah sistem. Sebagai sistem, aktivitas pendidikan terbangun dalam beberapa komponen, yaitu pendidik, peserta didik, tujuan pendidikan, alat pendidikan, dan lingkungan pendidikan. Semua komponen yang membangun sistem pendidikan, saling berhubungan, saling tergantung, dan saling menentukan satu sama lain. Setiap komponen memiliki fungsi masing-masing dalam rangka mencapai tujuan pendidikan. Aktivitas pendidikan akan terselenggara dengan baik apabila didukung oleh komponen-komponen dimaksud. Fungsi pendidikan sebenarnya adalah menyediakan fasilitas yang dapat memungkinkan tugas pendidikan dapat berjalan lancar, baik secara struktural, maupun secara institusional. Secara struktural menuntut terwujudnya struktur organisasi yang mengatur jalannya proses kependidikan. Secara institusional mengandung implikasi bahwa proses kependidikan yang terjadi dalam struktur organisasi itu dilembagakan untuk lebih menjamin proses pendidikan itu berjalan secara konsisten dan berkesinambungan mengikuti kebutuhan dan perkembangan manusia yang cenderung ke arah tingkat kemampuan yang optimal (Saat, 2015).

Pasal 1 UU SISDIKNAS no. 20 tahun 2003 disebutkan bahwa Sistem Pendidikan Nasional adalah keseluruhan komponen pendidikan yang saling terkait secara terpadu untuk mencapai tujuan pendidikan nasional. Berangkat dari bunyi pasal ini dapat diketahui bahwa pendidikan adalah sistem yang merupakan suatu totalitas struktur yang terdiri dari komponen yang saling terkait dan secara bersama menuju kepada tercapainya tujuan (Soetarno, 2003: 2). Adapun komponen-komponen dalam pendidikan nasional antara lain adalah lingkungan, sarana-prasarana, sumberdaya, dan masyarakat. Komponen-komponen tersebut bekerja secara bersama-sama, saling terkait dan mendukung dalam mencapai tujuan pendidikan. Tujuan pendidikan nasional yang dirumuskan dalam UU SISDIKNAS adalah untuk mengembangkan potensi anak didik agar menjadi manusia yang beriman dan bertakwa kepada Tuhan Yang Maha Esa, berakhlak mulia, sehat, berilmu, cakap, kreatif, mandiri, dan menjadi warga Negara yang demokratis serta bertanggung jawab (Munirah, 2015).

Pada hakikatnya pendidikan merupakan suatu usaha yang dilakukan oleh pemerintah melalui berbagai kegiatan bimbingan pangajaran atau latihan yang berlangsung di sekolah maupun di luar sekolah untuk mempersiapkan siswa agar mereka dapat memahami peranan dalam berbagai lingkungan hidup yang tepat untuk masa yang akan datang. Salah satu pertanda bahwa seseorang telah belajar sesuatu adalah adanya perubahan tingkah laku dalam dirinya. Perubahan tingkah laku tersebut menyangkut perubahan yang bersifat pengetahuan (kognitif) dan keterampilan (psikomotor) maupun yang menyangkut nilai dan sikap (afektif). Sehingga hasil belajar tampak sebagai akibat terjadinya perubahan perilaku pada diri siswa yang dapat diamati secara langsung dalam bentuk perubahan pengetahuan, sikap dan keterampilan. Oleh karena itu, proses belajar merupakan suatu kegiatan yang melibatkan peran aktif antara pendidik dan siswa sehingga dalam proses belajar mengajar dibutuhkan model pembelajaran yang memudahkan pendidik dalam menyampaikan materi serta memudahkan siswa dalam menerima dan memahami materi yang diajarkan sehingga dapat meningkatkan hasil belajar.

Menurut Suprijono (2012:5), hasil belajar adalah polapola perbuatan, nilai-nilai, pengertianpengertian, sikapsikap, apresiasi dan keterampilan. Selanjutnya Supratiknya (2012 : 5) mengemukakan bahwa hasil belajar yang menjadi objek penilaian kelas berupa kemampuan-kemampuan baru yang diperoleh siswa setelah mereka mengikuti proses belajar-mengajar tentang mata pelajaran tertentu. Dalam sistem pendidikan nasional rumusan tujuan pendidikan mengacu pada klasifikasi hasil belajar dari Bloom yang secara garis besar yaitu aspek kognitif, aspek afektif dan aspek psikomotor (Widodo, 2013). 
Keberhasilan belajar peserta didik dipengaruhi oleh beberapa faktor, dapat berasal dari diri peserta didik sendiri maupun dari guru sebagai pendidik. Faktor yang berasal dari guru di antaranya kemampuan dalam merancang pembelajaran yang mampu menumbuhkan motivasi belajar peserta didik, menciptakan suasana belajar yang menarik dan menyenangkan. Namun pada kenyataannya, peserta didik masih menganggap matematika sebagai mata pelajaran yang menakutkan sehingga susah untuk dipahami. Hal ini terjadi karena pendidik belum mampu mengemas pembelajaran matematika menjadi lebih menyenangkan yang mampu menarik perhatian peserta didik. Sehingga membuat prestasi belajar peserta didik tidak sesuai dengan yang diharapkan (Ayuwanti, 2016).

Metode Snowball Throwing merupakan salah satu model pembelajaran kooperatif. Metode pembelajaran tersebut mengandung unsur-unsur pembelajaran kooperatif. Snowball artinya bola salju sedangkan throwing artinya melempar. Snowball Throwing dapat diartikan sebagai metode pembelajaran yang menggunakan bola pertanyaan dari kertas yang digulung bulat berbentuk bola kemudian dilemparkan secara bergiliran di antara sesama anggota kelompok. Snowball throwing yaitu metode pembelajaran yang didalam terdapat unsur-unsur pembelajaran kooperatif sebagai upaya dalam rangka mengarahkan perhatian siswa terhadap materi yang disampaikan oleh guru. Suatu model pembelajaran merupakan rencana, pola atau pengaturan kegiatan guru dan siswa yang menunjukkan adanya interaksi antara unsur-unsur yang terkait dalam pembelajaran yakni; guru, siswa dan media termasuk bahan ajar atau materi subjeknya. Penerapan model-model pembelajaran diharapkan dapat menumbuhkan berbagai kegiatan belajar siswa sehubungan dengan kegiatan mengajar. Dalam interaksi ini pendidikan berperan sebagai pembimbing sedangkan siswasebagai yang dibimbing. Proses ini akan berjalan dengan baik apabila siswa lebih banyak aktif dibandingkan dengan guru, oleh karena itu model pembelajaran yang baik adalah model yang dapat meningkatkan keaktifitas kegiatan belajar siswa.Model pembelajaran kooperatatif Snowball throwing merupakan salah satu dari sekian banyak tipe pembelajaran kooperatif. Model pembelajaran kooperatif tipe Snowball thowring ini selalu diawali dengan membagi kelas menjadi beberapa kelompok, dimana setiap kolompok memiliki satu orang ketua yang akan mewakili teman sekelompoknya untuk mendengarkan penjelasan dari guru tentang materi yang akan di pelaJari. Setiap siswadi berikan kesempatan untuk menuliskan pertanyaan di selembar kertas mengenai hal-hal yang kurang atau belum mereka pahami guna membentuk pola pikir yang mandiri bagi setiap siswa. Belajar memerlukan keterlibatan mental dan kinerja siswa mandiri. Dalam model pembelajaran kooperatif tipe Snowball throwingsiswadapat belajar sambil bemain, sehingga dapat mengurangi kejenuhan siswa dalam mengikuti kegiatan belajar mengajar. Siswadibagi dalam beberapa kelompok untuk berdiskusi mengenai suatu materi dengan melakukan permainan yang dapat menciptakan suasana belajar menjadi lebih menyenangkan dan siswamerasa lebih santai dalam menjalani proses belajar mangajar, sehingga materi pelajaran dapat lebih mudah untuk diserap. Pembelajaran kooperatif tipe snowball throwing memiliki kelebihan dan kekurangan. Kelebihan model pembelajaran kooperatif tipe snowball throwing ialah dapat melatih kesiapan siswadan saling memberikan pengetahuan. Sedangkan kekurangan dari model pembelajaran kooperatif tipe snowball throwing yaitu pengetahuan tidak luas hanya berkutat pada pengetahuan sekitar siswa, dan tidak efektif. Model Snowball Throwing merupakan salah satu model pembelajaran yang dikembangkan berdasarkan pendekatan kontekstual (CTL). Snowball Throwing yang menurut asal katanya berarti 'bola salju bergulir' dapat diartikan sebagai model pembelajaran dengan menggunakan bola pertanyaan dari kertas yang digulung bulat berbentuk bola kemudian dilemparkan secara bergiliran di antara sesama anggota kelompok. Kegiatan melempar bola pertanyan ini akan membuat kelompok menjadi dinamis, karena kegiatan siswa tidak hanya berpikir, menulis, bartanya, atau berbicara. Akan tetapi mereka juga melakukan aktivitas fisik yaitu menggulung kertas dan melemparkannya pada siswa lain. Dengan demikian, tiap anggota kelompok akan mempersiapkan diri karena pada gilirannya mereka harus menjawab pertanyaan dari temannya yang terdapat dalam bola kertas (Yuliati, 2015).

Ketika peneliti melakukan wawancara dengan guru kelas IV yang bernama Ibu Herlina Dewi Rahmawati, S.Pd didapatkan informasi bahwa dalam mengajar pendidik belum menggunakan model pembelajaran yang bervariasi sehingga berpengaruh terhadap hasil belajar siswa yang rendah, pembelajaran masih bersifat konvensional serta penggunaan media yang kurang maksimal sehingga kurang menarik perhatian siswa saat proses pembelajaran.

Pembelajaran tematik adalah pembelajaran terpadu yang memakai tema untuk mengkaitkan beberapa mata pelajaran sehingga peserta didik mendapat pengalaman yang bermakna (Kunandar, 2011: 340). Guru haruslah kreatif baik dalam menyiapkan kegiatan belajar untuk siswa, juga dalam hal memilih kompetensi dari berbagai mata pelajaran dan mengaturnya supaya pembelajaran tersebut menjadi lebih menarik, bermakna serta menyenangkan, sehingga siswa siap dan aktif dalam mengikuti setiap kegiatan pembelajaran yang pelaksanaannya mungkin dibutuhkan untuk bekerja secara individual, kelompok kecil maupun klasikal. Namun pada faktanya ketika peneliti melakukan observasi awal di kelas IV SD Negeri 02 
Kemijen rata-rata nilai siswa pada pembelajaran tematik belum mencapai Kriteria Ketuntasan Minimal (KKM) yaitu 70. Berdasarkan data nilai UTS pembelajaran tematik siswa kelas IV dengan jumlah 40 siswa, persentase siswa yang memenuhi KKM sebanyak 37,5\% atau 15 siswa, sedangkan yang belum tuntas KKM sebanyak $62,5 \%$ atau 25 siswa.

Berkaitan dengan masalah diatas diharapkan dapat diatasi dengan menggunakan model pembelajaran yang memungkinkan siswa menjadi lebih aktif dalam pembelajaran, sehingga dapat memahami materi pelajaran yang disampaikan oleh guru dan tujuan pembelajaran akan tercapai. Salah satu model pembelajaran yang dapat digunakan adalah model pembelajaran Snowball Throwing. Menurut Huda (2014: 226) pembelajaran Snowball Throwing melatih murid untuk lebih tanggap menerima pesan dari orang lain, dan menyampaikan pesan tersebut kepada temannya dalam satu kelompok.

Penelitian ini sejalan dengan penelitian yang dilakukan oleh Januwardana (2014) dengan judul "Pengaruh Metode Snowball Throwing Berbantu Media Sederhana Terhadap Hasil Belajar Matematika Siswa Kelas V SD Gugus 1 Kota Badung". Rancangan penilitian yang digunakan adalah "Nonequivalent Control Group Design". Dalam penelitian ini menunjukan bahwa nilai posttest pada kelas eksperimen ratarata sebesar 75,22 yang mana lebih tinggi dari siswa kelas kontrol yaitu 67,00. Berdasarkan uji tes $t$ diperoleh bahwa terdapat perbedaan yang signifikan terhadap hasil belajar matematika antara siswa kelas eksperimen yang menggunakan metode Snowball Throwing dengan siswa kelas kontrol yang mendapat perlakuan dengan pembelajaran biasa (metode ceramah). Selain itu, sebagian siswa menunjukan sikap positif dan antusias terhadap pembelajaran matematika berbantu media sederhana ini dengan menggunakan metode Snowball Throwing.

\section{Metode}

Metode penelitian diartikan sebagai cara ilmiah untuk mendapatkan data dengan tujuan dan kegunaan tertentu (Sugiyono, 2017: 3). Metode penelitian yang akan digunakan pada penelitian ini adalah metode eksperimen. Metode eksperimen merupakan metode penelitian yang digunakan untuk mencari pengaruh perlakuan tertentu terhadap yang lain dalam kondisi yang terkendalikan (Sugiyono, 2010: 107). Desain penelitian yang digunakan dalam penelitian ini adalah Pre-eksperimental Design dengan model One-Group Pretest-Posttest Design. Design ini dapat di gambarkan sebagai berikut:

\section{$01 \times 02$}

$\mathrm{O}_{1} \quad$ : Nilai pretest (sebelum diberlakukan model pembelajaran Snowball Throwing berbantu media cakram kariku)

X : Diberlakukan model pembelajaran Snowball Throwing berbantu media cakram kariku

$\mathrm{O}_{2} \quad$ : Nilai posttest (sebelum diberlakukan model pembelajaran Snowball Throwing berbantu media cakram kariku).

Penelitian ini menggunakan sampel nonprobability sampling dengan teknik sampling jenuh, sehingga semua anggota populasi digunakan sebagai sampel. Teknik pengumpulan data yang digunakan yaitu tes, wawancara dan dokumentasi. Tes akan diberikan dua kali untuk mengukur hasil belajar tematik siswa. Tes awal (pretest) akan diberikan sebelum diberikan perlakuan dengan model Snowball Throwing berbantu media cakram kariku, sedangkan tes kedua diberikan di akhir pembelajaran (posttest) setelah diberikan perlakuan dengan menggunakan model Snowball Throwing berbantu media cakram kariku. Bentuk tes yang digunakan berupa soal pilihan ganda. Terdapat 2 variabel dalam penelitian ini yaitu variabel bebas dan variabel terikat.

a. Variabel bebas (variabel independen) dalam penelitian ini adalah model pembelajaran Snowball Throwing berbantu media cakram kariku dan selanjutnya disebut variabel X.

b. Variabel terikat (variabel dependen) dalam penelitian ini adalah hasil belajar tematik dan selanjutnya disebut variabel Y.

Teknik analisis data yang digunakan melalui beberapa tahap yaitu (1) uji normalitas awal dengan menggunakan pretest. Uji normalitas awal dilakukan untuk mengetahui subjek penelitian berdistribusi normal atau tidak, maka dilakukan uji normalitas dengan menggunakan uji liliefors; (2) uji normalitas akhir dengan menggunakan posttest. Uji normalitas akhir digunakan untuk mengetahui data yang akan dianalisis berdistribusi normal atau tidak setelah diberilakan perlakuan menggunakan model pembelajaran Snowball Throwing berbantu media cakram kariku, dalam tahap ini juga menggunakan rumus uji liliefers; (3) Uji ketuntasan hasil belajar, dalam penelitian ini dicari ketuntasan belajar individu siswa dan ketuntusan belajar klasikalnya; (4) Uji hipotesis, dalam penelitian ini menggunakan uji t-test. 


\section{Hasil dan Pembahasan}

Dalam penelitian ini terdapat 3 indikator keefektifan: 1) Jika terdapat perbedaan hasil pretest dan posttest pada uji-t. 2) Hasil belajar pada aspek kognitif, afektif dan psikomotor secara klasikal telah mencapai $75 \%$. 3) Siswa yang menjawab setuju pada angket respon siswa terhadap pembelajaran menggunakan model Snowball Throwing berbantu media cakram kariku mencapai 82,5\%.

Tabel 1. Hasil pretest posttest siswa kelas IV SD Negeri 02 Kemijen

\begin{tabular}{lccccc}
\hline $\begin{array}{c}\text { Jenis } \\
\text { Tes }\end{array}$ & $\begin{array}{c}\text { Nilai } \\
\text { Terendah }\end{array}$ & $\begin{array}{c}\text { Nilai } \\
\text { Tertinggi }\end{array}$ & Rata-rata & Siswa Tuntas & $\begin{array}{c}\text { Siswa Tidak } \\
\text { Tuntas }\end{array}$ \\
\hline Pretest & 30 & 83 & 60,85 & 15 & 25 \\
Posttest & 53 & 90 & 73,65 & 33 & 7 \\
\hline
\end{tabular}

Dari hasil penelitian tersebut diperoleh nilai terendah pada uji pretest sebesar 30 , nilai tertinggi sebesar 83, sedangkan pada hasil belajar posttest diperoleh nilai terendah sebesar 53, nilai tertinggi 90 . Dengan melihat rata-rata antara hasil belajar pretest dan posttest terjadi selisih 12,8 yang menunjukkan bahwa telah terjadi peningkatan hasil belajar yang signifikan setelah diberikan perlakuan menggunakan model Snowball Throwing dengan berbantu media cakram kariku.

Berdasarkan data tersebut kemudian dilakukan uji normalitas awal. Uji normalitas awal dilakukan untuk mengetahui subjek penelitian berdistribusi normal atau tidak, maka dilakukan uji normalitas dengan menggunakan uji liliefors. Dengan menggunakan $\mathrm{N}=40$ dan taraf signifikan 5\% maka diperoleh $\mathrm{L}_{\text {tabel }}=0,140$. Hasil uji normalitas pada uji pretest didapatkan nilai $\mathrm{L}_{\text {hitung }}=0,074$, sedangkan pada uji posttest didapatkan nilai $\mathrm{L}_{\text {hitung }}=0,120$. Karena didapatkan nilai $\mathrm{L}_{\text {hitung }}<\mathrm{L}_{\text {tabel }}$ maka data yang didapatkan berasal dari populasi yang berdistribusi normal.

Hal tersebut diperkuat menggunakan uji hipotesis dengan menggunakan uji- $t$ yang bertujuan untuk mengetahui perbedaan hasil pretest dan posttest. Dengan jumlah N = 40-1 = 39 dan taraf signifikan 5\% didapatkan nilai $t_{\text {tabel }}=2,064$, hasil dari uji- $t$ didapatkan nilai $t_{\text {hitung }}=11,264$. Karena diperoleh nilai $t_{\text {hitung }}>$ $t_{\text {tabel }}$ maka hipotesis yang diajukan diterima. Sehingga dari hasil uji-t tersebut menunjukan hasil antara pretest dan posttest terdapat perbedaan. Saat proses pembelajaran, peneliti juga menilai pada aspek afektif siswa. Aspek afektif yang dinilai yaitu teliti, kritis, kerjasama dan percaya diri. Hasil nilai aspek afektif dapat dilihat pada tabel dibawah ini.

Tabel 2. Hasil Nilai Sikap Teliti

\begin{tabular}{cccc}
\hline \multirow{2}{*}{ Pertemuan Ke- } & \multicolumn{3}{c}{ Nilai } \\
\cline { 2 - 4 } & Nilai Terendah & Nilai Tertinggi & Rata-rata \\
\hline 1 & 50 & 100 & 78,7 \\
2 & 50 & 100 & 85 \\
3 & 50 & 100 & 88,1 \\
4 & 50 & 100 & 90 \\
5 & 50 & 100 & 91,2 \\
6 & 50 & 100 & 91,2 \\
\hline
\end{tabular}

Tabel 3. Hasil Nilai Sikap Kritis

\begin{tabular}{cccc}
\hline \multirow{2}{*}{ Pertemuan Ke- } & \multicolumn{3}{c}{ Nilai } \\
\cline { 2 - 4 } & Nilai Terendah & Nilai Tertinggi & Rata-rata \\
\hline 1 & 50 & 100 & 82,5 \\
2 & 50 & 100 & 84,3 \\
3 & 50 & 100 & 88,1 \\
4 & 50 & 100 & 91 \\
5 & 50 & 100 & 90 \\
6 & 50 & 100 & 91,8 \\
\hline
\end{tabular}


Tebale 4. Hasil Nilai Sikap Kerjasama

\begin{tabular}{cccc}
\hline \multirow{2}{*}{ Pertemuan Ke- } & \multicolumn{3}{c}{ Nilai } \\
\cline { 2 - 4 } & Nilai Terendah & Nilai Tertinggi & Rata-rata \\
\hline 1 & 50 & 100 & 83,7 \\
2 & 50 & 100 & 85 \\
3 & 50 & 100 & 88,1 \\
4 & 50 & 100 & 89,3 \\
5 & 50 & 100 & 90 \\
6 & 50 & 100 & 91,2 \\
\hline
\end{tabular}

Tabel 5. Hasil Nilai Sikap Percaya diri

\begin{tabular}{cccc}
\hline \multirow{2}{*}{ Pertemuan Ke- } & \multicolumn{3}{c}{ Nilai } \\
\cline { 2 - 4 } & Nilai Terendah & Nilai Tertinggi & Rata-rata \\
\hline 1 & 50 & 100 & 80 \\
2 & 50 & 100 & 81,8 \\
3 & 50 & 100 & 83,7 \\
4 & 50 & 100 & 86,8 \\
5 & 50 & 100 & 90 \\
6 & 50 & 100 & 90,6 \\
\hline
\end{tabular}

Berdasarkan perhitungan, penilaian aspek afektif secara klasikal telah mencapai 75\% dimana pada setiap pembelajaran telah mengalami peningkatan. Hal ini terlihat dari pembelajaran ke-1 sampai ke- 6 dengan rata-rata penilaian aspek afektif pada pembelajaran ke-1 yaitu 82,6 , pada pembelajaran ke-2 yaitu 84,8 , pada pembelajaran ke-3 yaitu 87 , pada pembelajaran ke-4 88,8, pada pembelajaran ke-5 90,2, serta pada pembelajaran ke-6 yaitu 91,3.Teori belajar yang sesuai dengan penelitian ini yaitu teori behavioristik yang dicetuskan oleh Gage dan Berliner. Menurut Susanto (2017: 26) teori behavioristik lebih menekankan pada terbentuknya perilaku yang tampak sebagai hasil belajar dan perubahan tingkah laku sebagai hasil dari pengalaman. Sesuai dengan teori behavioristik jika anak diberikan pembelajaran dengan model yang menyenangkan, maka perilaku anak juga akan terbentuk dengan baik.

Aspek psikomotor juga dinilai dalam penelitian ini. Pada pertemuan ke-1 penilaian psikomotor yaitu membuat pertanyaan wawancara dalam bentuk teks tulis. Pada pertemuan ke-2 yaitu menyanyikan lagu "Tanah Airku". Pada pertemuan ke-3 yaitu membuat laporan hasil wawancara mengenai perubahan energi dan pemanfaatannya. Pada pertemuan ke-4 yaitu menuliskan ide pokok dari teks bacaan "Manfaat Minyak Bumi untuk Kehidupan Manusia". Pada pertemuan ke-5 yaitu menyanyikan lagu "Desaku yang Kucinta". Dan pada pertemuan ke-6 yaitu membuat laporan pengamatan dalam menjaga kelestarian lingkungan di sekitar tempat tinggal. Hasil nilai psikomotor siswa dapat dilihat pada tabel dibawah ini.

Tabel 6. Rekapitulasi Hasil Nilai Psikomotor Siswa

\begin{tabular}{cccc}
\hline Keterangan & Nilai Terendah & Nilai Tertinggi & Rata-rata \\
\hline Pertemuan Ke-1 & 50 & 100 & 80,6 \\
Pertemuan Ke-2 & 50 & 100 & 90 \\
Pertemuan Ke-3 & 50 & 100 & 83,3 \\
Pertemuan Ke-4 & 50 & 100 & 86,2 \\
Pertemuan Ke-5 & 50 & 100 & 93,7 \\
Pertemuan Ke-6 & 50 & 100 & 93,4 \\
\hline
\end{tabular}

Berdasarkan perhitungan penilaian aspek psikomotor secara klasikal juga telah mencapai $75 \%$ pada setiap pembelajaran. Hasil penelitian menunjukan bahwa model Snowball Throwing berbantu media cakram kariku dapat meningkatkan hasil belajar siswa, baik dalam aspek kognitif, afektif dan psikomotor siswa. Hasil ini didukung dengan jawaban responden pada angket respon siswa. 
Tabel 7. Respon Positif Siswa

\begin{tabular}{|c|c|c|c|c|c|c|}
\hline \multirow{3}{*}{$\begin{array}{c}\text { Butir } \\
\text { Pernyataan }\end{array}$} & \multicolumn{4}{|c|}{ Frekuensi } & \multirow{3}{*}{$\begin{array}{l}\text { Total (skor x } \\
\text { frekuensi) }\end{array}$} & \multirow{3}{*}{ Rata-rata } \\
\hline & $\mathrm{SS}$ & $\mathrm{S}$ & TS & STS & & \\
\hline & 4 & 3 & 2 & 1 & & \\
\hline Butir 1 & 12 & 28 & - & - & 132 & 3 \\
\hline Butir 2 & 15 & 18 & 7 & - & 128 & 3 \\
\hline Butir 3 & 13 & 26 & 1 & - & 132 & 3 \\
\hline Butir 4 & 12 & 26 & 1 & - & 128 & 3 \\
\hline Butir 5 & 21 & 17 & 2 & - & 139 & 4 \\
\hline Butir 6 & 13 & 25 & 2 & - & 131 & 3 \\
\hline Butir 7 & 12 & 25 & 3 & - & 129 & 3 \\
\hline Butir 9 & 15 & 21 & 4 & - & 131 & 3 \\
\hline Butir 10 & 21 & 17 & 2 & - & 139 & 4 \\
\hline Butir 11 & 15 & 19 & 6 & - & 129 & 3 \\
\hline Butir 12 & 13 & 24 & 2 & 1 & 129 & 3 \\
\hline Butir 14 & 16 & 23 & 1 & - & 135 & 3 \\
\hline Butir 15 & 19 & 20 & 1 & - & 138 & 3 \\
\hline Butir 16 & 11 & 15 & 14 & - & 117 & 3 \\
\hline Butir 19 & 16 & 22 & 2 & - & 134 & 3 \\
\hline
\end{tabular}

Dilihat dari jawaban responden dari angket respon siswa, dapat disimpulkan bahwa 82,5\% siswa menjawab setuju mengenai penggunaan model Snowball Throwing berbantu media cakram kariku pada pembelajaran tematik subtema 2 "Kayanya Negeriku" dapat meningkatkan hasil belajar, baik dalam aspek kognitif, afektif maupun psikomotor siswa

\section{Simpulan dan Saran}

Berdasarkan rumusan masalah, pengajuan hipotesis, analisis data penelitian dan pembahasan, maka peneliti menyimpulkan bahwa model Snowball Throwing berbantu media cakram kariku efektif terhadap hasil belajar siswa pada pembelajaran tematik subtema 2 kelas IV SD Negeri 02 Kemijen. Hal ini dibuktikan dengan (1) hasil uji- $t$ test sebesar 11,264 dengan taraf signifikan $\alpha=5 \%$ dan $t_{\text {tabel }}=2,064$, menunjukkan bahwa terdapat perbedaan hasil antara pretest dan posttest. Berdasarkan kriteria pengujian apabila diperoleh nilai $t_{\text {hitung }} \geq t_{\text {tabel }}$ atau 11,264 $\geq 2,064$ maka Ha diterima.Sehingga dari hasil uji- $t$ test tersebut menunjukkan hasil antara pretest dan posttestterdapat perbedaan. (2) Selain itu hasil belajar pada aspek kognitif, afektif dan psikomotor pada setiap pembelajaran mengalami peningkatan dan secara klasikal telah mencapai 75\%. (3) Sedangkan pada respon siswa mengenai penggunaan model Snowball Throwing berbantu media cakram kariku mampu meningkatkan hasil belajar siswa yang menjawab setuju mencapai 82,5\%, yang artinya penggunaan model Snowball Throwing berbantu media cakram kariku mampu meningkatkan hasil belajar siswa kelas IV SD Negeri 02 Kemijen.

Berdasarkan simpulan dari hasil penelitian tersebut disarankan bagi pihak sekolah bahwa penggunaan model Snowball Throwing berbantu media cakram kariku dapat diterapkan sebagai alternatif model pembelajaran yang dapat meningkatkan hasil siswa. Bagi para peneliti lanjutan penggunaan model Snowball Throwing berbantu media cakram kariku dapat menambah pengetahuan baru yang dapat diterapkan disekolah dimasa yang akan datang

\section{Daftar Rujukan}

Ayuwanti, Irma. 2016. Meningkatkan Aktivitas Dan Hasil Belajar Matematika Menggunakan Model Pembelajaran Kooperatif Tipe Group Investigation Di Smk Tuma'ninah Yasin Metro . Jurnal SAP Vol. 1 No. 2 Desember 2016 ISSN: 2527-967X

Huda, Miftahul. 2014. Cooperative Learning. Yogyakarta: Pustaka Pelajar.

Kunandar. 2011. Guru Profesional Implementasi Kurikulum Tingkat Satuan Pendidikan (KTSP) Dalam Sertifikasi Guru. Jakarta: Rajawali Pers. 
Januwardana, I Gd. Arta, dkk. 2014. "Pengaruh Metode Snowball Throwing Berbantu Media Sederhana Terhadap Hasil Belajar Matematika Siswa Kelas V SD Gugus 1 Kota Badung”. Jurnal Mimbar PGSD Universitas Pendidikan Ganesha, Vol. 2 No. 1 Tahun 2014.

Megawanti, Priarti . 2012. Meretas Permasalahan Pendidikan Di Indonesia . Jurnal Formatif 2(3): 227 -234 ISSN: 2088-351X

Munirah. 2015. Sistem Pendidikan Di Indonesia: Antara Keinginan Dan Realita . Jurnal Auladuna, Vol. 2 No. 2 Desember 2015: 233-245

Susanto, Ahmad. 2017. Teori Belajar dan Pembelajaran di Sekolah Dasar. Jakarta: Kencana.

Sugiyono. 2010. Metode Penelitian Pendidikan. Bandung: Alfabeta.

Saat, Sulaiman. 2015. Faktor-Faktor Determinan Dalam Pendidikan (Studi Tentang Makna Dan Kedudukannya Dalam Pendidikan) . Jurnal Al-Ta'dib Vol. 8 No. 2, Juli-Desember 2015.

Sugiyono. 2017. Metode Penelitian Pendidikan. Bandung: Alfabeta.

Widodo, 2013. Peningkatan Aktivitas Belajar Dan Hasil Belajar Siswa Dengan Metode Problem Based Learning Pada Siswa Kelas Viia Mts Negeri Donomulyo Kulon Progo Tahun Pelajaran 2012/2013. Jurnal Fisika Indonesia No: 49, Vol XVII, Edisi April 2013 ISSN : 1410-2994

Yuliati. 2015. Efektifitas Penggunaan Model Kooperatif Tipe Snowball Throwing Untuk Meningkatkan Hasil Belajar Siswa Pada Materi Sistem Pertidaksamaan Linear Di Kelas Xi-Is-2 Sma Negeri 7 Banda Aceh . Jurnal Peluang, Volume 3, Nomor 2, April 2015, ISSN: 2302-5158 